\title{
NUP98/NSD1 Fusion Gene
}

National Cancer Institute

\section{Source}

National Cancer Institute. NUP98/NSD1 Fusion Gene. NCI Thesaurus. Code C99434.

A fusion gene that results from a chromosomal translocation $\mathrm{t}(5 ; 11)(\mathrm{q} 35 ; \mathrm{p} 15.5)$ which fuses the first half of the NUP98 gene to the 3' portion of the NSD1 gene. This fusion is associated with myelodysplastic syndrome. 